\title{
WAR DAMAGE COMPENSATION AND RESTITUTION IN FOREIGN COUNTRIES
}

\author{
NeHEMIAH RoBinson* \\ I
}

\section{INTRODUCTORY}

This article deals with domestic legislation on war damage compensation and restitution. Therefore, all problems relating to reparations and their use for war damage compensation as well as to international restitution ${ }^{1}$ must remain outside the scope of this study. Similarly, international agreements concerning war damage compensation and restitution ${ }^{2}$ are excluded therefrom. Furthermore, we shall treat here of war damage compensation only in so far as it is not based on any insurance schemes for war losses in Allied and enemy countries during World War II.

"War damage compensation" is reparation of losses $^{3}$ sustained in a country at war (or in a neutral country which was subjected to such losses inadvertently by the belligerents ${ }^{4}$ ) by acts of war, enemy occupation, or their consequences. "Restitution" is the restoration of available property which was confiscated or sequestrated or was subjected to forced transfers by acts of the occupant or of the government or other authorities or of private persons in the country of the situs of the asset. In practice, "restitution" is not restricted to restoration of the object to the owner but also involves, within certain limits, compensation for losses sustained by the owner through and during deprivation of possession. The basis of the damage and the consequence of the act (in the first instance involving destruction of or damage to property or bodily harm and in the second, transfer of title) are different. None-

- Dr.rer.pol. (JENA) 1927. Director of the Institute of Jewish Affairs of the World Jewish Congress, New York. Author of publications on international law (minorities, Genocide, Human Rights), restitution and reparations, and international economics.

${ }^{1}$ International restitution concerns the obligation of the defeated enemy countries to restore property which they carried off during occupation of an Allied territory and/or which was found in their territory after the end of the war.

For the regulations enacted in occupied Germany and Austria see i.a., Robinson, Reparations and Restitution in International Law, The JeWISH YeArboox OF INTERNATIONAL LAW I97f. (r948).

Special provisions to this effect were also included in the Armistice Agreements and Peace Treaties with the satellite nations (Rumania, Bulgaria, Italy, and Hungary).

For the situation in Japan see I6 Dep'T State BuLl. 708 (April 20, I947) and I7 id. I000 (Nov. 23, 1947).

2 See, for instance, Art. 24(4) (war damage compensation) and Arts. 24 and 25 (restitution) of the Peace Treaty with Rumania and the corresponding articles in the other treaties.

${ }^{3}$ Damage to persons (life, limb, liberty) is included in this article only in so far as the basis for both kinds of loss is the same.

- To care for such cases Switzerland on July 3, I942, issued a decree creating a fund to cover damage caused by violations of its neutrality and supplemented this decree by another dated Aug. 2I, 1942 relating to the participation of the Federation in the expenses-involved.

In Sweden 2 law passed in 1939 provides for state insurance against war losses. - It covers mainly transport risks, including embargoes. 
theless, both are interrelated in as much as war damages embrace, in many instances, losses sustained as a result of confiscation or alienation of property if it is no longer in existence, if it was damaged, or if the despoiled person suffered other losses.

\section{War Damage Compensation 5}

\section{A. Introductory}

The legislation on war damage compensation in foreign countries differs from nation to nation. In broad terms, the foreign countries could, with regard to this legislation, be divided into five groups: (a) those in which a registration of such losses has been made but no action taken to assess, let alone compensate, the damage; (b) those where the principle of war damage compensation is recognized but no legislation has yet been enacted to provide for actual compensation payments; (c) those which carry on their statute books partial measures of compensation; (d) those which, in addition to insurance schemes, have certain regulations for common war damage compensation; and (e) those which have enacted and implemented comprehensive legislation to this effect.

\section{B. The First Group: Greece, Poland}

Examples of the first group are Greece and Poland.

In Greece the victims of war damages were requested immediately following the end of hostilities to submit declarations to the Ministry of Finance concerning their losses. The declarations were not based on law, they were not of an obligatory nature and served statistical purposes only, and the acceptance of registration by the General Accounting Office was not construed as a commitment that compensation would be paid. ${ }^{6}$. Since then no law has been promulgated for the compensation of these damages; the losses are of such a nature that nobody seems even to think of their reparation.

The situation is more or less similar in Poland. In 1945, the registration of war losses was ordered on the basis of a ministerial decree; all registrations by residents of Poland had to be made on or before February 15, 1946. Registration by foreigners was also accepted after that date, while registration abroad was made in the Polish consulates in accordance with special announcements. ${ }^{7}$ However, it was made clear at that time that the submission of registration served only statistical and legal purposes and did not imply that payment of the damages might be expected in the

- On the question of the rights of U.S. citizens to compensation in foreign countries and the overall problem of indemnification on the nationality or territorial basis, see Fraleigh, Compensation for War Damage to American Property in Allied .Countries, 4r AM. J. INT's. L. 748 (1947).

For lack of space legislation in Latin America (see, for instance, the Mexican decree of Scpt. I3. 1945, etc.) is not treated here.

'See 17 Dep't State Bull. 995 (Nov, 23, í947).

' In' the U. S. the time elapsed on April 30, 1947, but registration was continued for some time on the basis of a request for extension. 
near future. ${ }^{8}$ The registration was made on special questionnaires, with different forms for urban and for other residents, and containing space for listing immaterial damage (loss of life, etc.), losses in movables and real estate, and other damage (for instance, expulsion, confiscation of moneys, forced labor, fines, etc.).

C. The Second Group: Czechoslovakia, Yugoslavia, Burma

In Czechoslovakia the decree of August $3 \mathrm{I}, 1945^{\circ}$. provided for registration and assessment of war damages. These included losses suffered after October 17, I938, in Bohemia, Moravia, and Silesia (the three provinces of the country) and abroad by Czechoslovak citizens, as well as by Czechoslovak legal persons domiciled in the three provinces. The losses must have resulted from injury to life, limb, or health; from violent death, imprisonment, deportation, maltreatment; from expropriation or removal abroad of property; from destruction of property; or certain other damages. They had to be the result of action by belligerents, of persecution on political, national, or racial grounds by the German or Hungarian occupants or by organs acting on their orders, or of terrorist acts by organizations or persons hostile to the Czechoslovak State. The assessment of the losses was made on the basis of actually caused damage. Serving as such a basis in case of damage to property was the replacement value of the property on the effective day of the decree or the market price on that date; all other kinds of damages were to be assessed on the basis of existing general regulations for compensation of such losses. Submission of an application or the assessment did not secure a claim to compensation.

Somewhat simpler in substance were the provisions of the detailed Yugoslav law. of June IO, I945..$^{10}$ According to this law, war damages included damages caused to the person, estate, or income of Yugloslav citizens and legal persons ${ }^{11}$ in Yugoslavia and abroad by military action, acts of military and other authorities, and persons enumerated in the law. The losses were computed on the basis of the local currency (dinar) in accordance with prices prevalent on August 5, I94I. In cases of material damage the costs required to reestablish the old position were generally considered to represent the loss. Damages to life included non-received income and the costs required for the maintenance of dependents; losses of health, freedom, and similar non-material damage were computed on a similar basis. The declarations of damage had to be submitted in Yugoslavia within 40 days of the publication of the law; by persons residing abroad, within 40 days of the announcement by the Yugoslav diplomatic or consular representative. The assessment, on the basis of the declarations, was made by the District War Damage Commission.

In Burma claims for compensation for damage to property and certain goods

${ }^{B}$ See, for instance, Airgram from the U. S. Embassy.in Warsaw to the State Department, June-2r, 1946.

${ }^{\circ}$ Collection of Statutes and Orders, 1945, No. 54/55.

${ }^{10}$ Službeni List 1945, No. 4. For claims by U. S; citizens, see 21 Dep'r State Bull. 865a (P̣ec. 5, 1949).

${ }_{12}$ Curiously enough, damages caused to properties belonging to the state and its regionat subdivisions were included. 
could be filed with the War Damage Claims Commission. The purpose of the registration was only to reach decisions as to the exact liability to be assumed and it was made clear that the consideration of the claim and its assessment did not commit the Government to the payment of compensation. ${ }^{12}$

In Malaya and Singapore claims were registered with the War Damage Claims Commission. Legislation was reported to be under preparation to compensate for certain types of damage. ${ }^{13}$

\section{Germany and Austria}

The situation prevailing in Germany and Austria is peculiar in that the regulations issued during the war are not applied and no new general rules have so far been enacted. The basis for war damage compensation was the November 30, I940 ${ }^{14}$ War Damage Ordinance, under which compensation for damage due to war acts, deportation, flight, etc., was to be made either in money sufficient to restore the destroyed property or in the equivalent in kind; in the same manner, the cost of repairs was to be repaid. Some implementary regulations were issued subsequently, although most of the problems involved (for instance, how the cost of reacquiring the lost object was to be computed) were never settled.

After the end of the war, the Allies prohibited in Germany payments of claims under the war damage legislation. ${ }^{15}$ The only remedy available is that based on the Immediate Aid Ordinance of August $4,1949{ }^{16}$ whereby persons who suffered property damage as defined in the November 30 , I 940 Ordinance and are in need of assistance are eligible for it. Assistance consists in annuities, payments for building purposes and acquisition of home furnishings, as well as in grants for general economic rehabilitation.

In Austria owners of damaged houses are entitled to loans for reconstruction purposes on the basis of the law governing the Fund for the Reconstruction of Houses (Wohnungsaufbaufond-Gesetz). The means of the fund are raised by a special tax on the income from the rent of undamaged houses.

\section{E. The Third Group: Italy}

Basically, war damage compensation there is regulated by Law No. 1534 dated October 26, 1940, and Royal Decree No. 1957 of December 16, 1940.17 Subsequently a number of implementary regulations dealing with certain questions relating to the losses were issued by the competent Ministry. So far, only damage to the most

${ }^{12} 17$ Dep't STate BuiL, ro89 (Dec. 7, 1947).

1320 id. 87 (Jan. 16, 1949).

14 Reichsgesetzblatt, Part I, 1547.

${ }^{18} \mathrm{Sec}$, for instance, Ordinance No. 99 of the British Military Government, Schedule, Prohibited Expenditures referred to in par. 2 of Art. I. Mintirar Government Gazetre, Germany, British Zone of Contror, No. 21, p. 589 .

${ }^{\text {to }}$ For the law and its implementary regulations see, for instance, Kitz-Rauc, Gesetz ztur Milderung dringender sozialer Notstaende (Soforthilfegesetz) (Stuttgart and Cologne, 1949).

More comprehensive legislation is under consideration.

17 Gazzetta Ufficiale 1940, No. 270, and id. I941, No. 35. For the rights of U. S. nationals sec Art. is of the Peace Treaty. 
essential property, such as clothing, tools, and household utensils is being compensated in installments. The total value of claims submitted amounts to about 3 trillion lire, and the payments made thus far, to 80 or roo billion lire; in many instances only one installment has been paid so far. ${ }^{18}$ Payment of other damage awaits the enactment of a new law now in preparation. Eligible under the present regulation are Italian citizens and nationals of states which have concluded an agreement of reciprocity with Italy; no provisions exist in favor of stateless persons.

\section{F. The Fourth Category: Norway, Denmark}

In Norway war damage compensation in the strict sense of the word (i.e., other than insurance) is paid on the basis of the law of July 10, I946 on damages to buildings, and two laws dated April 25, r947, viz., Law No. 3 on war damage compensation for loss of movable property, and Law No. 4 on certain losses caused during the war of $1940-45 .^{19}$ Loss of movables is compensable in regions totally devastated by the Germans and provided the lost property will be replaced. If no claim under the insurance laws is possible, compensation is paid out of funds, allocated by the Parliament, by the Compensation Office of the Ministry of Justice. Included in exceptional cases are losses which are or should have been covered by insurance. Payment is not obligatory, i.e., the Office may grant compensation if the loss is considerable, the claimant is in need, and he behaved patriotically during the war. The ceiling is ro,00o kroner. Special consideration is to be given to the rebuilding of enterprises. Substantial losses caused by acts of patriotism and by arrest are compensable. Heirs receive compensation in exceptional cases only.

As a rule, only Norwegian citizens residing in Norway are eligible. Excluded are owners of property whose conduct during the war was not satisfactory (German collaborators, for instance). Stateless persons who have lived in Norway for at least 20 years are in practice placed in the same category as Norwegians.

Denmark provides more comprehensive non-insurance compensation for losses sustained during German occupation. The basis for compensation is Law No. 475 of October $\mathrm{r}$, I945. ${ }^{20}$ The law covers loss of life, imprisonment, deportation, damage incurred through participation in the liberation movement (opposition to the German occupant), damage to property, loss of profession, interruption of study, and the like. Compensation is restricted to Danish citizens and to German citizens who were Danish citizens before I933.

\section{G. The Fifth Group: France, Belgium, Luxembourg, Holland}

France $^{21}$ is the traditional country of comprehensive war damage compensation. ${ }^{22}$

18 These data are based on information received in June, I950, from the Sottosegretariato per i Danni di Guerra.

10 Norsk Lovtidend, No. 15, 1947. tion.

21 Prior to the law described below, a number of decrees were issued to provide for partial compensa-

${ }^{22}$ For Algeria, see decree No. 47-1467 of Aug. 9, I947 extending the validity of Law No. 46.2389 to that region. The same law was made applicable in Tunisia by virtue of the Tunisian decree of July 17 , 1947. Concerning Morocco, see I9 Dep't State Bull. 2 I I (Aug. I5, I948). 
The laws of April I7, rgrg; and of June, Igrg, issued after the First World War, recognized the right of damagees to full indemnification of their material and personal losses suffered in consequence of the war. This rule was followed in principle during and after the last war. The laws of 1940 and $194 \mathrm{I}$ provided for the participation of the state in the costs of reconstructing destroyed houses. Law No. 46.2389 of October $28,1946^{23}$ on war damages regulated anew the right to indemnification of material damages, while the earlier law of May 20, I946, simply put again into operation the provisions of the law of June 24, I919, concerning civilian victims of the war. Law. No. 46.2389 was supplemented with a number of implementary laws, decrees, regulations, and circulars. ${ }^{24}$

The purpose of the law of October 28 , 1946 , is not so much indemnification of the damagee ${ }^{25}$ as reconstruction of the country. Thus compensation is granted only ion the basis of an obligation by the damagee to rebuild the destroyed property. ,He has to accomplish this task not according to his own wishes but in accordance with the requirements of existing economic plans and urban legislation. The next feature of the law is based on the financial impossibility to repay all losses at once. "Therefore, although the principle of "integral", reparation is recognized, actual payment. is made on the basis of priorities; ceilings for immediate compensation are established and certain property is exçluded. An. order of priorities has been fixed on the bâsis of a long-range program. ${ }^{26}$ The ceilings for immediate payments depend on the nature of the property and its ownership: in the case of movables of current use, the ceiling is 200,000 francs; in the case of real estate, it is 5,000,000 franes. Amounts above this ceiling may be paid up to 70 per cent pending the elaboration of a final scheme of compensation. No compensation is paid for luxury articles, movables not of current or family use, monetary losses, and losses not exceeding 3,000 francs.

Under the law material and direct.losses caused by events of war are compensable. These include, in addition to military action and sabotage, a number of other acts, such as occupation by the enemy resulting in destruction or deterioration of property; requisitions; damage to boats, etc. Certain damages are presumed to be the .result of.war events, for.instance, losses caused to persons expelled by the enemy, pillage during the war, and so.on.

Eligible to compensation under the law are French citizens and their successors

${ }^{23}$ Journal Officiel, Oct. . 29, 1946..

${ }^{24}$ For a full list of these enactments up to 1947 sec Alain LE TAP.Nec, Les Rècles Nouvelles de

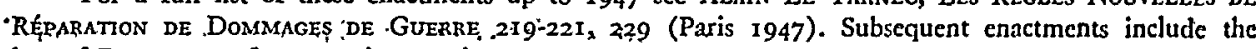
law of Dec. 3I, 1948, concerning maximum amounts.

${ }^{25}$ The material damages "weré of such magnitüde that 'iñdemnification pure and simple could not be achieved within the existing budgetary limitations: 310,000 houses were completely destroyed and 926,000 partially; 53,000 -agricultural enterprises completely demolished and 160,000 partially. . The trumber of industrial and commercial enterprises totally and partially destroyed was ten times jarger than during the First World War. The total amount of the damage was 4,500 billion francs. ..

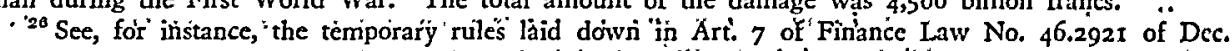
23, 1946. At "present these priorities are established for each department" (province). 
in right, French legal persons, nationals of the French Union, foreigners who themselves served or whose ascendants or descendants served in the armed forces of France or its Allies during the First or Second World Wars, and Frenchmen who acquired real estate from a foreigner. Other persons are eligible to receive compensation if the right is based on international agreements. ${ }^{27}$ Loans are granted for purposes of urgent reconstruction, or when this is useful to the French economy, to persons not otherwise coming under the law. Those excluded from the benefits of the law are, within certain limitations, collaborators and some other condemned persons. A requisite condition for: compensation is that the damage occurred in France or in a French overseas possession. Compensation for losses suffered by French physical and legal persons abroad not indemnifiable on the basis of reciprocal agreements was left for subsequent legislation.

- The total amount paid out for purposes of 'war damage compensation in the

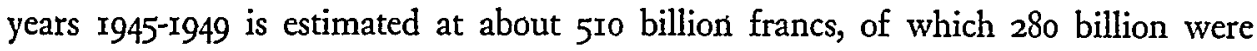
paid in 1949 .

- Belgian legislation on war damage compensation consists of two general measures, viz., the law of October $\mathrm{r}$, 1947, relating to damages to private property, and the law of July 6 , i948, concerning property required for public services. In addition, there are a number of laws and decrees dealing with special damages, such as military servitude, and requisitions. ' In execution of the law of October I, 1947, a considerable number of laws and decrees were promulgated. ${ }^{28}$

The basic law of October $x, 1947$, refers to direct and material damages caused by war events on Belgian territory to movable property and real estate and to boats outside of Belgium. Small losses are excluded. War evients include acts done in connection with the war and occupation (except military requisitions), crimes against private property, forced evacuation, and unkniown causes which resulted in the destruction of merchandise, etc., between May Io and 3I, I94I, and between Aṕril 8, 1944, and February 15, I945. Only physical and legal persons who were of Belgian nationality on the day of damage and on the effective date of the law are eligible, except in so far as international agreemeñts próvide otherwise.29 By decree certain categories of stateless persons and foreigner' may be granted the same treatment as Belgians on the basis of their activity against the enemy. 'On the other hand, the law excludes a number of persons, such as those condemned for crimes against the security of the state, those who participated in spoliation, etc.

\footnotetext{
${ }^{27}$ For instance, stateless persons assimilated in their civil rights to citizens; U. S. nationals on the basis of the U. S.-French agreement on commercial policy and related matters dated May 28,1946 (see I6 DeP'T State BuLL. I66 (Jan. 26, 1947)).

i: ${ }^{28}$ For all this legislation sce, i.a., 'Vranck, $L a{ }^{\prime}$ Réparation des Dommages de Guerre aux Biens, $\mathrm{L}_{A}$ Charte (1949).

For prior legislation concerning material and immaterial losses see NEHEMIAH RoBINSON, INDEM, NIFIcatjon and Reparations 8 (SUPp. II), (INSTtTute of Jewish AfFairs, i 1945-46).

$\therefore{ }^{20}$ Sce, for instance," the British-Belgian agreement of June 7,1948 ; on reciprocity in war "damage compensation. "Registration' of claims was accepted from foreigners. I8 DeP'T STATE BuLl. 278 .(Feb. 29, 1948).
} 
The assistance granted by the state consists of indemnification, graded according to the total funds of the damagees, and of guaranties for credits to them. A system of priorities is established, ${ }^{30}$ based on the position of the damagee, the availability of manpower and material, the state of the Treasury, and the economic needs of the country; special considerations are given to small houses, furniture, small traders, and professionals. The law requires the damagee to use the indemnity for reconstruction purposes.

To implement compensation, Caisse Autonome des Dommages de Guerre was established by the law of May 19, 1948. It was guaranteed an appropriation by the state of 2.5 billion francs annually for fifteen years, and has certain other income provided by law. ${ }^{31}$

War damage compensation in Luxembourg is paid on the basis of the law of February 25, 1950, and the decree of March 15, 1950, on the declaration of such damage. ${ }^{32}$ Compensation is granted for damage to property, for loss of income by persons damaged by the enemy, and for bodily harm. Destruction, deterioration, carrying off and loss of property caused by acts of war or occupation, pillage, evacuation, deportation, and similar events are considered damage to property. Eligible are Luxembourg citizens (even if they resided abroad) and stateless persons and foreigners who have resided in Luxembourg since 1930 and contributed signally to the welfare of the country. The first category has a right to indemnification, the two others may be compensated by a decision of the competent authorities. Excluded are persons who committed crimes against the state, participated in spoliation, whose conduct during occupation was not proper, etc.

Compensation is made, within the limits of the budgetary appropriations, on the basis of priorities which take into account the special needs of victims of Nazism, the financial position of the damagee, and the economic needs of the country. Consequently, in case of destruction of real estate, the same building must be reconstructed at the same place. In case of property losses, compensation is granted only if it serves to rehabilitate the damagee economically and socially. Reparation may also be made in natura; state bonds may be substituted for actual payment. All losses under 3,000 francs are excluded; similarly, indemnification is refused for luxury articles, not used for commerce.

Holland's war damage legislation is based on decrees F. 98 of June 16 , 1945 and F. 255 of November 9, 1945, as well as on decrees of the Minister of Finance. According to these regulations, losses sustained in consequence of warfare, war activities, and measures taken by the enemy, including confiscation of household goods (except moneys, jewelry, and luxury articles), and industrial equipment and goods, are indemnified. Indemnification is limited in certain cases; for instance,

\footnotetext{
${ }^{20}$ Art. $8(3)$ of the law and decree of June 18,1948 .

${ }^{31}$ These amounts, apparently, are based on the total value of known claims, which on Nov. 30, 1948; amounted to over 35 billion francs. Belgians claimed 33,27 I millions, foreigners the rest.

${ }^{32}$ Mémorial du Grand-Duché, March 27, 1950.
} 
losses of household goods and similar objects are compensated only to the maximum amount of 5,000 florins. Otherwise the difference between the value of the object before and after the damage is considered the indemnifiable loss.

Holland is one of the few countries in which almost no difference exists between citizens and foreigners in the enjoyment of compensation, in so far as they reside there. Persons who on May Io, I940 or later were of enemy nationality must obtain a non-enemy certificate. ${ }^{33}$

\section{III}

\section{RESTITUTION $^{34}$}

\section{A. Introductory}

The problem of restitution of property confiscated from, or transferred under duress by, victims of racial, religious, or political persecution engaged the interest of the governments concerned from the very beginning of the war. This preoccupation was based on the experience in Germany and Austria during the years I9331939, and its main purpose was to assure the victims that spoliation would not be assented to and to impress upon the would-be acquirers that they would not be permitted to keep the assets after Allied victory. The Governments-in-Exile of Poland, Belgium, Luxembourg, Yugoslavia, Norway, and Greece issued laws and decrees to this effect. The Czechoslovak Government made a declaration which was given the validity of a law, and the French Committee of National Liberation made a decree ordering the execution of the United Nations Declaration of January 5 , I943 to which reference is made below. Of these measures, the Belgian, Luxembourgian, and Norwegian laws were put into operation and the French built their restitution legislation around the aforesaid decree. The Polish decree of November $30,1939,{ }^{35}$ the Yugoslav decree of May 28, $1942,{ }^{36}$ the Czechoslovak declaration of December I9, $194 \mathrm{I}^{37}$ and the Greek decree of October $22,194 \mathrm{I},{ }^{38}$ remained on the statute books of the Governments-in-Exile. ${ }^{39}$

${ }^{33}$ About the status of United States citizens and those of some other countries see decree of Sept. Io, I947 and I7 Dep't State Bull. 332 (Aug. I7, 1947) and I7 id. 9 Io (Nov. 9, 1947) and Report of the War Clatms Commission 34 (Washington, 1950).

For the situation in the Netherlands Indies see Report of THE WAR Claims Commission 36 (Washington, 1950).

"Asia (for instance, the Netherlands East Indies' Ordinance for juridical restoration published in Staatsblad r947, No. 70; China, Hong-Kong) is not dealt with here. See, i.a., 17 Dep't State Bull. 835 (Oct. 26, 1947), 17 id. 1000 (Nov. 23), 17 id. 1090 (Dec. 7, 1947), and 18 id. 278 (Feb. 22, 1948).

Similarly, restitution of property seized as enemy assets remains outside the scope of this study. (For Japan and Thailand, see I7 Dep'T State Bul. 49 (July 6, 1947), 19 id. 245 (Aug. 22, 1948), 20 id. 1433 (April 3, 1949), and 22 id. at 245 (Feb. 13, 1950); for the Netherlands East Indies, see Report of the War Claims Commission 36 (Washington, 1950)).

${ }^{95}$ Dziennik Ustaw Rzeczypospolitej Polskiej, No. 12, Dec. 2, 1939.

so Sluzbene Novine, June 18 , 1942 .

${ }^{27}$ Interallied Review, 194I, No. 11.

${ }^{88}$ Greek Official Gazette No. 172, Oct. 28, 1941.

"For their contents, see RobInson, IndeMnification aNd Reparations, op. cit. supta, note 28, at 118 fr. 
The problem of spoliation played a considerable role in the waging of the war. Through these acts Germany and her allies acquired large funds which they were able to use for purchases abroad, especially as far as gold, securities, and similar valuables were concerned. To counteract this tendency and to strengthen the morale of the despoiled, the Allies issued many warnings, the most important of which was the above-mentioned United Nations Declaration of January 5, I943. ${ }^{40}$

Restitution is the undoing of deprivation of property. It must therefore be adapted to the confiscatory measures of the depriver. These measures varied in the various countries which at one time or another came under the direct or indirect control of Germany. Restitution is simple if the property was taken over by a central governmental body and remained in the possession of the government. It becomes more complicated if the confiscated property was later transferred to private persons. Still more complications arise if the assets were transferred under duress but by acts ostensibly legal. On the other hand, the measures used to effect restitution had to reflect the general legal and economic tendencies in the country of application (see, for instance, the cases of Hungary or Poland), as well as such imponderabilia as precedents, conservatism in legislation, etc. In some countries restitution legislation was enacted immediately after the end of the war; in others it took quite a long time. In the second case conservatory measures were sometimes enacted designed to make a census of the properties affected, prevent their dissipation, and prepare for actual restitution by permitting voluntary filing of claims. It is therefore hardly surprising that restitution legislation and implementation vary considerably from country to country. In some cases a large number of legislative acts (some of them-for example the Hungarian legislation-dealing with minute details of spoliation) have been promulgated; in other instances several laws, and in still others one single comprehensive enactment, exist. The authorities called upon to effect restitution are in certain cases administrative bodies (especially when the property is in the hands of governments); in others (even where simple restoration could be carried out by a public body) all action is taken by courts; there also exist semi-judicial bodies. The speed of effecting restitution depends on the body called upon to act, the number of court instances established, the more or less complicated nature of the procedure, and the zeal with which this remedy is applied. The picture therefore varies and in most instances hardly conforms to the expectations of a speedy restoration of violated rights:

A second type of divergency is created by the fact that a certain amount of spoliated property found its way into other countries than that of its origin. As a result, the countries involved may be divided into two major groups: countries of the original situs of the spoliated property and those to which such property was transferred under whatever guise (neutral countries).

Legally, restitution is the result of the wrongfulness of the act of alienation; " ${ }^{\circ}$ CMD. No. 6418 (1943). 
sometimes it is the result of an act (confiscation, seizure) or transaction (transfer under duress) which at the time it was committed or effected was "legal" under the existing arbitrary laws, especially if this happened in a country where sovereignty was exercised by the local authority (Germany, Italy, Rumania, etc.), even if this authority was under pressure of another state, and became illegal with the abrogation of the discriminatory legislation. In other cases (occupied countries) the acts and transactions were illegal $a b$ initio (totally or partially) ${ }^{41}$ from the viewpoint of the real sovereign, and in contradiction to existing international law; ${ }^{42}$ sometimes they were even prohibited by the real sovereign. ${ }^{43}$

Ordinarily, the claimant has a right to restitution. But in some cases the competent authorities are granted wide powers of discretion in deciding upon restitution per se and the conditions under which it has to be effected. The legal remedy also varies: sometimes it is automatic nullity of the act or transaction which caused alienation; in other instances nullification is granted only upon request filed with the competent authority; often only a presumption of duress in favor of the owner is established. The legal value of the presumption is by no means uniform: it may be rebutted under strictly defined conditions only or it represents simply a reversal of the onus of proof.

In practice, restitution is not a simple act of returning property, because the transferred assets were used and did not remain untouched by time and wear and tear. Some property is consumed by use, other property loses a considerable part of its value; even real estate depreciates in time and is subject to deterioration. Mismanagement of the spoliated property causes further losses to the legal owners. On the other hand, most of the property provides income which-in the case of commercial and industrial enterprises-may over a long period of time even surpass the original value of the asset. Real estate (and in some instances, movables) may have been burdened with mortgages and other encumbrances by the illegal acquirer (the purpose of which varied from permanent improvements to raising moneys for the personal use of the possessor) or been destroyed by war acts or otherwise or, on the contrary, the possessor may have repaid such debts or made improvements in the assets. All this involves the problem of the responsibility of the possessor (or subsequent possessors) toward the owner and vice versa, which has found different solutions in various instances and countries. The foregoing is true to an even larger extent of commercial and industrial enterprises where management is the key to success, where stocks change rapidly and, in consequence of war scarcities, etc., may be completely exhausted or, due to good business, be increased manifold. Such enterprises may be combined with others or transformed into companies of a different legal personality or liquidated. If the asset was expressed in currency units it may have lost almost all of its value during alienation on account of inflation.

\footnotetext{
"1 The degree of illegality is also dependent on the temporary laws of the Governments-in-Exile mentioned above.

"See, for instance, the Fourth Hague Convention on Land Warfare.

${ }^{\star 3}$ For example, under the aforementioned Greek decree of 1941.
} 
Third parties are also involved in restitution, e.g., owners of newly created mortgages, creditors of the alienated enterprises, etc.

In practice, a differentiation was often made in regard to restitution and the mutual responsibilities of the possessor and owner, between property confiscated outright and property transferred under duress against payment, as well as between the various degrees of duress exercised toward the owner, and between the persons who acquired the property in the knowledge of the previous confiscation or the duress in which the owner had found himself and those who did not have this knowledge, or between the first and subsequent acquirers. The problem of fair or unfair price paid by the acquirer was one of the most vexatious of all, as was the good or bad faith of third persons. In many instances (even when wrongful deprivation was generally assumed) movables and especially bearer certificates were as a rule held to have been acquired in good faith and restitution refused, unless proven otherwise; often the title of the acquirer was held to be so strong that movables were not restored at all. Bonds and stocks sold through ordinary channels constituted a special case.

A special problem was presented by the repayment of the consideration received because of the difference in the value at the two dates (loss and reacquisition), the circumstance that the owner had in many cases been deprived of the right to dispose of it and the fact that-due to persecution-the owner did not possess the funds when restitution was applied for. A similar problem was presented by repayment of income received from the property and the right of the possessor to compensation for management.

Even the person of the claimant provoked in practice serious difficulties. Many of the original owners had been annihilated together with their next of kin. In most countries the law admitted all legal heirs as claimants; in others the right of restitution was restricted to near relatives (for instance, Austria, Poland). The problem of the disposition of heirless or unclaimed property presented very serious difficulties and did not find a uniform solution. ${ }^{44}$ Sometimes (for instance, in Yugoslavia and Hungary) a differentiation was made between persons living in the country of the situs of the property and absentees, the latter not always being recognized as claimants. The nationality of the owner was as a rule of no importance in regard to the right of restitution (contrary to war damage compensation), but in some instances restitution to foreigners was treated differently, as, for instance, in the case of "moral duress" in Belgium or apartments in France. The right of restitution was, as a general rule, also restricted in time, i.e., deadlines were established whose end automatically annulled the right of the person concerned to claim restitution. Nationalization of property conflicted with restitution and, as a rule, was given priority over it. In such cases the kinds of property subject to restitution were reduced considerably.

The foregoing is a sample of the difficulties which restitution encountered in the

"This problem is dealt with in a separate article of this symposium. 
various countries. No uniform solution was ever sought, much less applied. Furthermore, in many countries only the main features of restitution were considered by the legislators, while in others (especially in Germany) practically whole codes were written to effect restitution. But even the most detailed laws could not foresee all the problems involved in invalidating thousands upon thousands of transfers different in nature, duration, and conditions. This task devolved upon the courts (or other implementary bodies) which, in dealing with specific cases or on a general basis, had to fill the loopholes or clarify obscure provisions. The French court practice in restitution matters is very extensive and well publicized. ${ }^{45}$ Austrian and German jurisprudence is becoming more and more voluminous, ${ }^{46}$ while in other countries much less court practice is available. The volume of decisions depends on the number of cases, the complexity of the relations between restitutor and restitutee, and the attitude of the courts toward the whole problem.

The following presentation deals, for lack of space, mainly with the broad lines of the implementation of restitution in the various countries, since a detailed study of even a single nation with comprehensive legislation and practice would exhaust the space available for the whole article.

\section{B. Restitution in Neutral Countries}

Among the neutral countries, the main enactments are the Swiss, Swedish, and Portuguese.

The Swiss, as early as August 20, 1945, issued a decree concerning temporary measures (attachments) in expected lawsuits involving the right of ownership and possession of movables lost in war-stricken areas. The main purpose was to prevent the disappearance of the object. A further, more permanent, measure was enacted by the Federal Government on December ro, r945, viz., the decree concerning lawsuits involving restitution of property alienated in occupied countries. ${ }^{4 T}$ The decree deals with movables and securities (except those imported on the basis of normal international trade agreements) of which the owner was deprived in occupied countries, contrary to international law or by force, confiscation, requisition, or similar action of the military and civil authorities of the occupant; it is also applicable to cases where the owner transferred the property voluntarily but under the influence of deception or of well-founded fear for which the aforesaid authorities were responsible. The decree distinguishes between a bona and a mala fide acquirer: the former is entitled to repayment of the consideration paid to the seller, except when the applicable ordinary law provides otherwise. If the legal owner received compensation for the alienation, he has to repay it when the property is

${ }^{15}$ For years, practically every issue of the Gazette du Palais carried several such decisions.

"For Austria, see, i.a., Herler-Raucher, Die Rechtsprechung der Rueckstellungsאommisstonen (Vienna, 1949).

For German court practice see Rechtsprechung zUM WiedergutmaneHungSREcht, an appendix to the NEUE JURUSTISCHE WOCHENSCERIFT.

${ }^{\text {IT }}$ See also the decree of Feb. 22, .1946, concerning the search for property looted from occupied countries. 
restituted. The rights of third persons in the property are annulled. All thèse cases are déalt with by a special chamber of the Federal Supreme Court.

On June 29, 1945, Sweden promulgated a law concerning restitution of certain properties emanating from an occupied country, and another on control of certain foreign property. ${ }^{48}$ The first law provided for the obligation to restore property found in Sweden which had been seized contrary to rules of international law by violence or threat or other improper means by the occupying power, as well as assets of which the owner had been deprived by pillage; properties imported into Sweden on the basis of an international agreement were exempted. 'The implementation of the law was entrusted to a Board with full powers to seize and restore the property, order compensation, and provide for other required measures; it was authorized to refer the case to ordinary courts with the consent of the possessor of the spoliated property. The second law served mainly to preserve from sale or other disposition such property as might be subject to restitution.

Portugal enacted Decree-Law No. 34455 of March 23, 1945 on spoliated properties and implemented it by Decree No. 34600 of May 14, I945, providing for the nullity of transactions in personal property imported into Portgual when it could be proven that the owners had been despoiled by acts of the military occupant or by confiscation. Decisions are rendered by courts. These enactments also deal with transactions in negotiable instruments, registration of properties, investigation of the origin of the properties, etç.

\section{.C. Restitution in Belligerent Countries}

I. Bulgaria. Bulgaria enacted legislative measures which were the result of the specific conditions under which the transfer had occurred previously, viz., the liquidation of these assets through the Commissariat of Jewish Affairs. ${ }^{49}$ According jews (Institute of Jewish AfFaIRs, New York, 1943).

to the decree-law of February 24, 1945 on the material consequences of the abrogation of anti-Jewish laws, ${ }^{50}$ all real estate confiscated by the state was restituted to the owners; if it had been transferred in the meantime to third persons, the transfer was to be annulled by the authorities. Acquisition of property in rural communities was to be annulled upon request of the owner. Confiscated enterprises, movables, moneys, and valuables were returned, otherwise compensation was paid. Sales of movables effected. by the Commissariat or Tax Collector and liquidation of enterprises were declared void. Transfers to third persons made after August 3I, r944, were void; earlier transfers could be declared null if the possessor knew of their origin. Similarly, all transfers of shares, businesses, and participations by the despoiled persons themselves or by the Commissariat to third persons effected after September I, I940, could be declared void, but only upon an application which had to be made within three months from the effective date of the.decree. The decree also contained

\footnotetext{
${ }^{48}$ Swedish Statute Book (July I4, 1945).

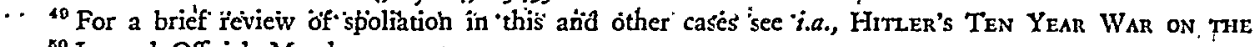

so Journal Officiel, March 2, 1945.
} 
a number of special regulations concerning revalidation of insurances, restitution of pharmacies, compensation for non-restitutable property, etc.

2. Norway. The situation in Norway is in some respects similar to that in Bulgaria. The law of December I8, I942, enacted by the Government-in-Exile, was in effect only until replaced by the provisional law of September 2r, $1945^{51}$ and by the Law No. 27 of December I3, I946, on confiscated property. Since the property of persecutees had been taken over during the war by the Liquidation Office for Confiscated Property, the laws of 1945 and 1946 established a Restitution Office for such property which administers all confiscated assets and assists former owners to regain them. Real estate and mortgages are restituted unconditionally, regardless of the good faith of the present possessor. The same is true in most cases of movables, but shares are restored in certain instances only. The Restitution Office pays back to the owners the accumulated balances for property disposed of during the war (in cases where no restitution has taken place); the difference between the amounts repaid and the total value is considered as war damage.

3. Luxembourg. Restitution in Luxembourg is based on the decree of April 22, r $94 \mathrm{I}$ as amended on July $7,1944 .^{52}$ According to these enactments, all acts of disposition and encumbrances of properties which were subjected by the enemy, since May Io, r940, to confiscation, seizure, forced sales, and other measures violating private property, are null and void. They may be reclaimed from every possessor without repayment of the price; the possessor has only the right of claiming the amount paid from the seller. The courts have to order the seizure of such properties; in the absence of restitution the judge has to impose, for the benefit of the damaged party, an indemnity equal to their value..$^{53}$

4. Greece. The Greek restitution legislation is based on three laws: Law No. 2 of October 25, I944, Law No. 337 of May 20, I945, and Law No. 808 of December 3r, I945. A large portion of confiscated property was in the possession of the Greek Treasury; therefore the legislation deals with the restitution of properties held or sought by the Treasury, or in the hands of appointed administrators or of private persons. The Treasury restitutes the property in the same way as it received it; if the assets are in the hands of administrators or private persons, the claimant has to submit to the holder a request for restitution through a judicial constable. If the property is not restored within 15 days from the receipt of the request, a claimant has the choice of appealing to court or to the Jewish Property Restitution Bureau. Special provisions exist for movables: the administrator is required to restore them to the Properties Administration Bureau without special application. All possessors of properties coming under the law must report them to the authorities.

E1 Norsk Lovtidend No. 15, Sept. 21, I945.

${ }^{53}$ Both texts were published in the Mémorial du Grand-Duché de Luxembourg, Sept. I8, I944.

${ }^{53} \mathrm{Cf}$. the decree of August 17 , 1944 (Mémorial, Sept. 20) concerning the sequestration of enemy property. This decree permits the Office of Sequestration to seize all properties which belonged after May 10, 1940, to the enemy state even if they were transferred to third persons who acted in bad faith. On the basis thercof many a restitutable property came under the jurisdiction of the Office. 
The administrators are required to submit an account of their activity. Leases made during dispossession are invalid. Those authorized to request restitution are the owners, their relatives up to the fourth degree, or relatives by marriage acting as trustees.

If assets received by an administrator are non-existent, the owner is entitled to compensation; a special application to this effect must be filed with the courts.

5. Italy. In Italy two periods of alienation are to be discerned: before and after the abdication of Mussolini (and the establishment of the new Fascist regime). Decree No. 26 of January 5, 1944, dealing with the first period, distinguishes between real estate which was forcibly transferred to the Institute for the Administration and Liquidation of Immovable Property (on the basis of Law No. 126 dated February 9, 1939) and still in its possession; property which the Institute transferred to third parties; gifts; enterprises sold to third persons; enterprises transferred to incorporated companies by the authorities; and other property. In the first two cases the owner has the right to request restitution upon return of the consideration received. Other real estate can be reclaimed if there is incontestable proof that the transfer was made to avoid the application of racial legislation. Gifts can be revoked only with the consent of the other party. On the other hand, private enterprises and partnerships transferred to third parties or given to "incorporated companies" may be reclaimed upon repayment of the consideration received. Special provisions exist for improvements, income from normal management, mortgages, etc.

Spoliation not covered by the foregoing decree was dealt with by Decree-Law No. 222 of April 12, I945, concerning supplementary norms. ${ }^{54}$ It provides for the right to cancel gifts, for the belated acceptance of inheritances and legacies, and for the cancellation of transfers made under the compulsion of racial legislation (provided the damage sustained exceeds one-fourth of the value of the property), and of fictitious contracts made to evade the application of the racial legislation.

The legislative decree of May 5, 1946,5 treating of property confiscated, sequestrated, or otherwise alienated under the regime of the so-called Government of the Social Republic, permits reclamation of all such properties from any possessor, except in case of third persons who acted in good faith. The law provides for an accounting by the possessor for the period of his administration and for payment of damages which occurred during his administration unless they were due to causes beyond his control. If the property was in the possession of the state the owner may claim, instead of restitution, the amount received from the sale of the property, including any increase in the selling price by subsequent transfers.

6. Rumania. In Rumania several periods of more or less vigorous persecution existed. Accordingly, the restitution legislation has established different criteria for various periods.

\footnotetext{
84 Gazzetta Ufficiale, May 22, 1945. An additional law relating to restitution is Decree-Law No. 896 of April 24, 1948 concerning restitution of property removed by the Germans.

${ }^{68}$ Gazzetta Ufficiale, June 7, 1946 .
} 
The decree-law of July 30, 1945, concerning the annulment and revocation of certain acts of transfer concluded under exceptional circumstances, ${ }^{56}$ distinguishes between four kinds of transfers. The first embraces a large number of transfers: transfers made under the "Rumanization" program to certain officials and other beneficiaries of this program or by owners who were detained, imprisoned or deported, or cases in which the property involved was, under the laws of the country, subject to transfer to the state, or in which the transfer was financed with state funds. In all these instances the transfer is to be voided upon application by the former owner; however, in certain cases the applicant has to prove that the transfer caused him a loss. In the second category of transfers the law establishes only a refutable presumption of duress; these include, i.a., transfers of small businesses within a certain period of time, as well as contracts concluded in the earlier period of persecution with members of certain organizations. A third category consists of so-called simulated transfers, for instance, transfers to former associates or employees of the transferor, or transfers providing for the financing of the enterprise by the transferor. Finally, the law provides for the revocation of all donations made within the period of persecution to avoid the consequences thereof.

The treatment of third parties differs in the various instances; while in the first two the annulment works unconditionally also against third parties who acquired real rights in the transferred property, in the case of movables, third parties are affected only if bad faith exists. Bad faith exists if the third party knew of the origin of the goods or-where enterprises are involved-if the acquirer cannot prove lack of such knowledge. As a rule, the owner has to receive the property in the same condition as when it was transferred. Therefore he must be compensated for losses (except those caused by possessors in good faith), and repay the consideration received and all investments and expenditures for extensive repairs made, within six months; real rights established after the transfer are charged to the purchase price.

Annulment and voidance are conditioned upon an application being made within three months from the date of the law; longer time limits are granted to absentees and deportees. Decisions are made by the civil courts, which apply accelerated procedures and eased proofs.

Special measures of restitution were introduced in North Transylvania (which was under Hungarian domination during the war) by the decree-law of August 13 , 1945. The decree provides three remedies: (a) annulment of transfers, pure and simple; (b) a presumption of duress; (c) annulment on certain conditions. The first category comprises transfers concluded between August 30, 1940, and October 25, 1944, if the claimant lived in North Transylvania and was subject to deprivation of liberty, or if he lost his position as a result of persecution, or suffered a loss amounting to at least $5^{\circ}$ per cent of the value, or was deported, expelled, or fled and suffered

so Monitorul Official, August I, 1945 . The earlier decree of Dec. 19, 1944, dealt only with certain aspects of restitution. 
a loss of at least 25 per cent, or if the property was put under forced administration and the loss amounted to at least 25 per cent. Claimants who suffered a loss of at least 25 per cent but do not come within the first category may request annulment on the basis of a presumption of duress. The third category embraces transfers made under threat of expulsion, deportation, arrest, etc., as well as expropriation for public purposes if the property was transferred to private persons afterwards. The annulment operates also against subsequent acquirers but, in the case of movables, only if they were aware of the conditions under which the first transfer had taken place.

- In addition to restitution, the former owner is entitled to compensation for the deterioration of the objects, but must repay the purchase price and refund all expenses which resulted in an increase of the value; there is no obligation to repay the income derived.

7. Yugoslavia. Yugoslavia has restricted restitution for a number of reasons. The law of May 24, I945, as amended on August 2, 1946, denies restitution to all citizens of Yugoslavia living abroad who refuse to return to the country. Another restriction is imposed by the provision that property whose restitution is contrary to the interest of the national economy, or national reconstruction, or the military security of the country is not restitutable provided a request to this effect is made by the competent authority within the specified period; however, the law provides for the payment of compensation in such instances. Restrictions of another nature exist in regard to the assignment of the administration of properties to near relatives of absent owners: the courts may decide to assign to them only a part of the total assets; moneys, securities, and valuables are to be assigned only if this is required for the administration of the enterprise.

Restitution is granted in all cases of properties, whose owners had to leave the country during occupation, of which they were deprived against their will, or which were transferred under the pressure of the occupant to third persons, regardless of who is in their possession, or the basis of possession. Property within the meaning of the law is real estate, businesses, securities, and property rights, including premises. The owner is entitled to the restitution of the income derived, within the limits of relevant provisions of the Civil Code. The same rules are applicable to businesses; however, in the case of enterprises which were in business during the occupation, restitution of the sold movables cannot be claimed. Real rights created after dispossession are to be annulled, except those covering investments made. Real rights achieved by a bona fide possessor are to be compensated by the owner; in the case of mala fide possessors the amount is due to the state. In case of damages or losses to the property, the owner is entitled to claim compensation.

All cases of restitution are to be dealt with by the courts. Until a court decision is reached the property is administered by special state organs. In order to facilitate :restitution, the law decrees the obligatory tegistration of all properties coming under 
its provisions within a month from the date of publication of such an order, and their transfer to the Committee for National Property.

8. Poland. The Polish decree of March 8, $1944^{67}$ contains two sets of restrictions on restitution: (a) properties transferred to the state on the basis of the nationalization law of January 3, 1946, and those coming under the law of the agrarian reform and similar enactments are exempt from restitution; (b) only the owner, his ascendants and descendants, spouses, brothers, and sisters are entitled to ask for restitution. As in the case of Yugoslavia, the properties are, pending restitution, administered by a special authority (State Offices of Liquidation).

Properties coming under the law are considered as abandoned and are divided into three groups: (a) properties of persons who lost possession thereof as a result of the war, including assets seized or confiscated by the occupant; (b) properties assigned to third persons for safeguarding; and (c) rental rights to business premises representing an indivisible part of the business.

Restitution is the result of the nullity of the acts of the occupant or of the legal transaction involved. In order to obtain restitution the owner or his heirs must institute proceedings with the town court of the situs of the property, unless the authority administering the asset consents to its return. The courts'apply the usual procedure but with such deviations as are required to speed up the decision; proofs are relaxed considerably.

Under the law, all possessors of the property (except those who were entrusted with it) are considered to be in bad faith if they acquired it by a void act or transaction. They must repay the income derived and are not entitled to claim the return of investments even if the value of the property was enhanced thereby. Only the state and public bodies and bona fide possessors are repaid the amount of investments to the extent of the increase in value.

One of the peculiarities of the Polish decree, which makes it unique and is the result of the general legal insecurity, is the provision that the claimant, if he is not the owner according to the register of deeds or similar registers, does not acquire the ownership of the property through restitution but only the right of administration and usufruct; ownership is acquired either by additional (normal) procedure or by undisputed possession within to years. During this period persons with better rights (for instance, closer relatives) may file a claim for the same property. Another peculiarity is the requirement of a special registration tax representing a certain percentage of the value.

9. Czechoslovakia. Czechoslovakia has introduced in its restitution legislation the notion of persons excluded from the remedy which-as seen above-is usual in war damage compensation: "nationally untrustworthy" persons have no right to regain their lost property. It has also made a distinction in respect to the social position of the owner:

${ }^{67}$ The earlier law of May 6,1945 , was amended by this decree. 
The restitution legislation of Czechoslovakia consists of two enactments: the decree of May I9, 1945 on the invalidity of certain legal transactions, and the law of May 16, 1946 , issued to implement the first decree. ${ }^{58}$

The first decree, although providing for the nullity of transfers effected under the pressure of the occupant, left the implementation of this rule to further legislation, except in so far as special rules were laid down in the decree concerning the restitution of property in the possession of nationally unreliable persons (namely, members of the German and Hungarian national parties and groups including persons who identified themselves with these groups, except those who can prove their loyalty to the Republic; persons engaged in activities contrary to the interests of the Czechoslovak Republic; and certain companies). In such cases, owners who are workers, farmers, craftsmen, small and medium industrialists and merchants, civil servants, professionals, and persons in similar positions are entitled to request restitution (provided they are not nationally unreliable) from the state authority which administered their property.

The law of 1946 invalidated all transfers and transactions concluded subsequently to September 29, 1938, under pressure of occupation or persecution, except when the acquirer is a nationally reliable person and can prove that he paid a fair price and acted either on the request or in the interest of the former owner. Similarly treated are transfers based on revoked regulations which were contrary to the Czechoslovak Constitution or on which racial, national, or political persecution was based. The owner and his successors in right may reclaim the property from the possessor. Exempt from restitution are properties in the hands of third acquirers who prove that they neither knew nor could have known of the original duress; all acquirers are jointly responsible for the damage. The claim is aimed at restitution of the property or restoration of the former situation. If this is impossible or the owner has no interest therein, or if the present possessor urgently needs the movables, compensation may be ordered in lieu of restitution. Restitution or restoration is also considered impossible if it militates against important public interests. The possessor is responsible as a mala fide acquirer for losses, income, expenses, etc.; if he was forced to acquire the property or safeguarded it against loss, his responsibility is only that of a bona fide acquirer. On the other hand, the former owner is required to restore the consideration or anything else he received.

All claims under the 1946 law are considered by the court of the residence of the respondent or the situs of the property.

Io. Belgium. Belgium has gone its own way in matters of restitution. On January 10, I941, the Belgian Government-in-Exile issued a decree and an implementary law on the measures taken by the occupant. ${ }^{50}$ These acts nullified all those measures $a b$ initio regardless of whether they involved public law, administrative measures, the social order, private law, or the interests of the citizens. The imple-

ss Sbirka Zakonu a-nařizena republiky Czechoslovenske No. 55, June 17, 1946.

${ }^{10}$ Moniteur Belge, Feb. 25, 194r; see also the explanatory note to this legislation, ibid. 
mentary law stipulated that all acts of disposition or burdening of property effected by the enemy after May Io, I94I, through confiscation, seizure, forced sales, or similar measures, were null and void. In consequence, the owner might reclaim the property from any possessor, within three years from the end of the war; the latter was not entitled to reimbursement from the owner of the price paid but might seek redress from the seller. No difference was made between bona and mala fide acquirers.

The above enactment thus dealt with acts and transactions resulting from a direct measure of the enemy but did not touch upon transfers made to evade forced sales or to procure moneys required to subsist, or to transfers made before deportation, hiding, etc. To fill out this gap, Belgium on April I2, 1947, enacted a law establishing a legal presumption in favor of certain persons, victims of "moral" compulsion. Under this law come all transactions concluded during the occupation by persons who on account of their race, nationality, opinions, political activity, or residence were exposed to measures of spoliation or sequestration by the occupant or his agents. It established a legal presumption that all these transactions were carried out under "moral" compulsion and may therefore be annulled in accordance with the respective provisions of civil law, thereby facilitating the establishment of proof of duress by the persecutees. The presumption may be refuted if the acquirer proves that the transaction would have also taken place on similar terms in the absence of persecution. In the case of third acquirers, the owner must prove that they knew of the origin of the property; however, the presumption is valid with regard to subsequent acquirers if the property consists of real estate, businesses, and other assets whose transfer is subject to public notice. The remedy of the law was granted to United Nations nationals and to nationals of neutral countries, stateless persons, and citizens of enemy states expelled from their country because of their race or opinion, but only if they had been admitted to an Allied country before September I, 1939 .

The problem of restitution of premises was dealt with in Belgium by a special decree, that of March I2, 1945, ${ }^{\circ 0}$ which provides for the possible reinstatement in their lost apartments of tenants who lost their homes or professional premises under duress, regardless of the good faith of the new lessees. The judge is granted wide powers of discretion with respect to reinstatement and the delays which he may grant to the present tenant.

Similarly, the problem of lost securities was treated separately; ${ }^{61}$ it was provided, i.a., that the dispossessed holder of bearer certificates might request restitution from any person who acquired them prior to publication, and that he need not re-

17d., March 15, 1945.

${ }^{42}$ Decree-law of May 18, I945, concerning involuntary dispossession of bearer certificates (Id., May 30, 1945).

Cf. the Ministerial Order of May 26, 1945 (Id., June I, 1945) concerning evidence of ownership in Belyian bearer certificates. 
imburse the purchase price if acquisition was made within a specified term, unless bought on the stock exchange or.from à registered bank.

II. Hungary. . The restitution legislation of Hungary is even more peculiar. It consists of a considerable number of enactments which vary in their provisions and application. ${ }^{62}$ In general, transfers of a usurious nature made under duress, as well as unilateral payments made during the period of persecution, are voidable. Duress is presumed on the basis of the existence of a discriminatory decree. At the same time the existence of-losses as a result of the transaction is to be verified. Business premises, real estate used for business, fixtures; goods, and stocks of stores, and movables are restitutable if they were lost on account of the owner's being a Jew. Special regulations exist in regard to certain licenses (for pharmacies, etc.). Ext cluded from restitution is landed property affected by the agrarian reform law. If the movables are in the possession of public authorities or institutions, political parties; and some other institutions, the right of reclamation is suspended, although the right of claim remains valid. If confiscated clothing, household implements, and furniture were assigned to persons in an emergency situation, they cannot be reclaimed as long as the emergency persists. A further peculiarity is the provision that the competent authorities may order a division of the lost-premises or goods between the legal owner and the acquirer; in certain instances the claim may be rejected, and in others only the right to compensation is granted. Movables cannot be reclaimed from a subsequent acquirer, unless he is closely related to the first acquirer or the transfer was gratuitous. There are also special rules concerning animals, private collections, and some other goods.

The right to restitution is restricted to the owner, his spouse, children, grandchildren, brothers, and sisters. In the absence of any such persons, a custodian is appointed to make the claim. Abandoned property of absentees is forfeited to the state; an exception may be made for persons who left the country to evade the application of discriminatory legislation.

Ordinarily courts are competent to deal with restitution cases. However, if the property lost.consists of premises, stores, and furniture, the claim may be filed with a special arbitration commission.

12. Holland. Restitution in Holland, based on Decree No. E. roo, of September I7, I944, as amended by Decree F..272 of November I6, ' 945 , is not of a mandatory: nature, as is usual elsewhere, but is largely left to the discretion of the Council for Reestablishment of Justice. Under the law, the Council is authorized to declare null and void, totally or partially, legal relations affected or changed during enemy occupation if, in its judgment, the omission of such intervention would be inequitable. Such omission-unless the contrary is proven-would be inequitable if the change was, effected by force or under undue influence of the occupant or persons acting in his stead or without legal cause or on the basis of enactments by the enemÿ

" ${ }^{\text {an }}$ The most important of them are Order 200/1945 M.E. Feb. 5, r945; Decree 7.590/r945; Decree No. 10490 of Sept. 11, 1946; Decree No. 300/1946; and Law No. XXVIII of May 24, 1945. 
which have been declared void. ${ }^{63}$ All decisions are made on the basis of equity and justice. Acting under the authority of the law, the Council may order restitution of the alienated objects and rights, unless the possessor proves his good faith (i.e., the absence of knowledge or suspicion that the object was lost under such conditions as would make restitution inequitable) in acquiring them, or that he obtained them from a third party against payment or from a person who had acquired them against remuneration; an exception is made in cases where the object is of considerably higher value to the owner than to the possessor.

If restitution is ordered, the owner must, as a rule, repay the consideration received and compensate the possessor if the ground for restitution is the higher value to him. Real rights established during alienation are annulled, except if acquired in good faith or against payment. The Council decides at its discretion about the fate of personal rights and the income derived. If restitution of the object or income is not ordered, although it would be in the power of the Council to do so; if the object was lost; if the rights of third persons in the object are maintained; if restitution is made against payment; or if the restituted objects suffered damage which would not have occurred in the absence of alienation, the Council grants compensation to the owner. All mala fide possessors are held responsible; the amount of compensation is equal to the loss the owner sustained by not having the property restored or by having it restored with encumbrances or against payment.

There are special rules for restitution of stocks and bonds. They are to be registered and delivered to the registering body; claimants to such stocks and bonds have to turn to this body for recognition. Recognition is granted if ownership and subsequent loss are proven.

Properties confiscated by German authorities are dealt with by three bodies: (a) the Custodian of the Deutsche Revisions-und Treuhand A. G., if the assets were sold (merchandise, bank balances, debts, and other liquid assets); (b) the Custodian of Lippmann, Rosenthal \& Co., for Jewish property; (c) the Trusteeship for Enemy Household Goods, for furniture and household goods. ${ }^{64}$

13. France. In France ${ }^{65}$ restitution has proceeded in several stages. Following the decree of November 12, x943, issued by the French Committee for National Liberation, ${ }^{86}$ the Provisional Government on October 16 , 1944 , enacted a decree

os $C f$. the decree of Sept. 17, 1944 on the legal effect of occupation measures.

It is noteworthy that Holland was the only occuoied country which did not enact any provisions of this kind during the war.

04 For further details, see Department of State Press Releases Nos. 255 (March 27, 1947), 357 (April 28, r947) and 617 (July $31, \mathrm{rg} 77$ ).

of The first territory to be freed from occupation and to enact restitution legislation was French North Africa. See the Giraud decree of March I4, 1943, the decree of April 3, I943 of the Governor-General of Algeria, and the corresponding regulations in the other territories.

Decree No. 45-770 of April 2I, I945, was also made applicable in Algeria. Special decrees were issued to apply this decree in other French territories (see, for instance, Decrees Nos. 49-6II of April 2I, I949 and ${ }_{46-493}$ of Feb. I, I950, extending the validity of some of the French restitution laws to Indo-China).

${ }^{\circ 0}$ Journal Officiel, Nov. 18, 1943. 
providing for immediate restitution of properties which had been entrusted to the Administration of Domains in accordance with the anti-Jewish legislation and had not been sold or transferred to third persons. Restitution was effected ex officio by the competent authority or on the basis of a simple demand by the owner. The next step was the decree of November 14, 1944, amended by the decree of February 2, I945 dealing with properties which had been subjected to acts of sequestration, provisional administration, or management or liquidation on the basis of legal measures of the Vichy Government or the German occupant. The owner of such properties automatically regained them upon request addressed to the administrator or manager thereof, provided they had not been subjected to acts of liquidation or disposition by August 19, 1944 (the date of restoration of Republican legality). Restitution had to be effected within a month and an account of administration or liquidation submitted within two months. If the property had been liquidated or disposed of, the owner was entitled to receive the corresponding amount, maintaining his rights in all other respects. The owner had to comply with the engagements entered into by proper acts of the administrator. ${ }^{67}$

To deal with the more complex problem of properties which had been subjected to acts of disposal or forced transfer, the French Government enacted Decree No. 45.570 of April 21, $1945^{68}$ (amended on June i9, 1947 by granting the possibility of annulling bankruptcy and judicial liquidation decisions in the same way as had earlier been provided in case of transfers). Here a distinction is made between exorbitant measures of common law and "voluntary" transfers.

- Persons whose properties, rights, and interests were subjected-even though with their material concurrence-to acts of disposition through sequestration, provisional administration, management, liquidation, confiscation, or any other "exorbitant measure" of common law in force on June 16,1940 , in consequence of legislative and other acts of the Vichy Government or of the German authorities, are entitled to establish the nullity of the acts of disposition. The dispossessed owner regains the properties, rights, and interests without obligations and mortgages assumed by the possessors, but with all improvements and new accessories. The first and subsequent possessors are generally regarded as of mala fides, unless they prove that they acquired possession upon demand of the Vichy authorities and either to avoid the transfer of economically or artistically valuable goods to the occupant or to safeguard the interests of the dispossesed owner in an accord with the latter. Mala fide possessors are not entitled to invoke the right of retention for their claims and are bound to restore to the owner all usufructs (natural, industrial, and civil) beginning with the date of retroactive nullity; bona fide possessors are also obliged to return the usufructs. The owner regaining his property is bound to repay to the possessor the

\footnotetext{
${ }^{\circ 7} \mathrm{Cf}$. the decree of Feb. 9, $\times 945$ concerning the responsibility of administrators; that of Jan. 9, 1945 regarding illicit profits made by administrators; and that of Feb. 3, 1945 (amended on May 23, 1945) on expenses of administration.

ea Journal Officiel, April 22, 9945.
} 
price paid by the latter, including the interest thereon, but only to the limit the owner has profited from this amount. The possessor may demand, furthermore, the reimbursement of the necessary expenses made for repairs, etc., and the useful expenses so far as the value of the property was augmented thereby. In such cases, the judge is obliged to grant the owner sufficient time to enable him to repay these amounts out of income from the property. The possessor is responsible for losses incurred through his acts of commission and omission; if the owner is unable to obtain the indemnity because of the absence or bankruptcy of the possessor or the administrator, the state will reimburse him in accordance with provisions to be promulgated in respect of war damage. If the properties, rights, and interests have been impaired or partially lost, the owner is ipsa lege substituted for the possessor in all of the latter's actions or rights against the insurer or third persons responsible for the damage.

Alienated movables are treated in accordance with the legal provisions for lost or stolen goods; they may be reclaimed within one year after the legal cessation of hostilities.

As far as "voluntary" transfers are concerned, the law provides for the legal presumption that contracts made after June 16, I940, concerning the transfer of movables, of rights to real estate and commercial enterprises, of rights to industrial, literary, and artistic properties, of partnerships in commercial firms, and of securities and similar valuables, made either by direct transfer of title to the bearer or contracts on registered stock by persons enumerated above, are considered as having been concluded under duress. However, if the possessor proves that he paid a fair price, the burden of the proof of the existence of duress rests on the former owner. The consequences of annulling the contract are those attributed by common law to nullity resulting from lack of consent; the former owner is obliged to reimburse the price paid, the necessary expenses for repairs, etc., and those which have augmented the value of the property or right, within the limits of this increase. The possessor is entitled to retain the usufructs up to the date of the request for annulment. The same rules are applicable in case of transfers without remuneration. Delays in repaying the costs of improvements may be accorded to the owner. If the possessor knew the actual position of the owner and did not pay a fair price, the rules laid down in regard to forced transfers are to be applied.

The law provides certain exceptions to the general rule of nullity and restitution. First, its provisions are not applied to securities sold on the stock exchange or through a banking institution without indication of the owner, unless the first or any subsequent possessor knew their origin. Furthermore, the law is not applicable to goods, rights, and interests requisitioned or expropriated for public purposes or acquired by the state in consequence of its right of eminent domain, unless these goods, rights, and interests were put under sequestration or provisional administration in consequence of the laws and regulations of Vichy, and the authorities decide that 
their remaining in state ownership does not comport any more with the concept of a public purpose. The owner must repay the amount equal to that fixed at the time of acquisition.

The law provides a remedy in case of an increase in the number of shares effected after the transfer of the original number: the owner is entitled to demand their cession by paying the amount of subscription. If the owner has become a holder of minority stock, he is entitled to refuse to take it back and to demand instead its value on the day of the request for restitution.

To facilitate restitution, the law prescribed that transfers of goods, rights, and interests falling under this law made after the coming into force of the law of August 9, 1944, concerning the restoration of Republican Legality, were null and void. Whoever held or had held, under any title whatever, goods, rights, or interests coming under the law, was obliged to declare them to the Ministry of Finance within a month, stating the name of the former owner, and the manner in which he had acquired and transferred them; the same obligation was incumbent on persons who had received any kind of movables in trust after June I6, I940.

Restitution by amicable settlement was facilitated through the provision that the court had to assess on mala fide acquirers an amount equal to ro per cent of the value in favor of the Treasury; similarly, upon request of the Ministry, the difference between the fair price and the price actually paid could be levied on the acquirer as a "civil" fine if that difference exceeded one fourth of the fair value.

The three decrees were supplemented by Decree No. 45-I224 of June 9, 1945, concerning transfers and transactions apparently legal made in favor of the enemy; the decree of November 14, 1944, concerning restitution of premises; the decree of April II, I945, relating to movables pillaged by the enemy and recovered by the state; the law of September 4, I947, concerning the assimilation of certain dispossessions to war damages; and Law No. 48-978 of June 16, I948, providing for the repayment of the amounts levied on the proceeds of alienation or other spoliation by acts of the Vichy Government.

14. Austria. The main peculiarity of restitution in Austria, which makes it unique, is the distinction made between "restoration" (Rueckgabe) and "restitution" (Rueckstellung). The first deals with properties alienated between March 5, 1933 and March 13,1938 (the Schuschnigg period), the second with assets expropriated or forcibly transferred during the period of German domination.

Restoration is based on the laws of February 7, 1947 and June 22, 1949. ${ }^{60}$ They provide for the restoration of properties which were owned by democratic organizations in the political, economic, and cultural fields (Social-Democratic Party, Christian Labor Organization, Communist Party, and their associations) and confiscated or alienated without remuneration on the basis of measures inconsistent with the laws in force on March 5, 1933. Restoration of the cancelled leases to houses and plots of which these organizations were deprived is also provided for.

${ }^{\circ 0}$ Bundesgesetzblatt (BGBL), 1947, No. 55 and 1949, No. 165 . 
Restitution has been a slow process in Austria. Action began on May ro, 1945, with a decree providing for a census of Aryanized or otherwise alienated properties; it was followed up by the law of February $\mathrm{I}, \mathrm{I} 946$ providing for the appointment of public administrators (which was disapproved by the Allies and became law in the amended form of July 26 , I946).

Restitution in Austria has followed procedurally the same course as in France. As in the latter, the first enactment was a general nullification of all transactions and other legal acts made during German occupation in connection with its political and economic penetration of Austria. ${ }^{70}$ It was followed by the First Restitution Law of July 23, $1946^{71}$ which provided for the restitution of alienated properties at that time under the administration of the Austrian Federation or Laender. The properties were to be restituted in the existing state with the available usufruct. Real rights established for the benefit of third persons were declared void; expenses incurred during alienation were to be repaid on the same basis as provided for negotiorum gestors. The law restricted the right of claim to spouses, ascendants and descendants, brothers and sisters of the owner, and children of the brothers and sisters; other relatives were entitled to claim the property only if they had lived in the same household with the owner. Restitution had to be effected by decision of the Finance Land Office or the authority which administered the property; appeals to the Ministry of Property Control were permissible. The second measure of restitution, the law of February $6,1947^{72}$ (Second Restitution Law), provided for restitution of properties alienated arbitrarily or by virtue of laws, on racial and similar grounds, which thereby became the property of the Austrian Republic. The terms of restitution were the same as in the First Restitution Law; and the same authorities passed upon the applications.

The basic enactment is the Third Restitution Law of February 6, $1947^{73}$ dealing with restitution of properties wrongfully alienated during the German occupation, arbitrarily or on the basis of laws or other enactments, including legal transactions or other legal action. Such alienation is especially assumed if the owner was subjected to political (including racial) persecution by the Nazis and the acquirer does not prove that the transfer of property would have taken place independently of the seizure of power by the Nazis. In the absence of political persecution, wrongful alienation is not assumed if the acquirer proves that the owner freely chose the buyer and received adequate compensation, or that the transfer would have taken place independently of Nazi accession to power. However, not all alienated properties are subject to restitution; movables acquired at a public auction or from a businessman authorized to deal in such property, and similar cases are exempted from the provisions of the law. If the movables were acquired at the establishment

\footnotetext{
${ }^{70} \mathrm{Law}$ of May 15, 1946 (BGBL, 1946, No. 109).

${ }^{71} \mathrm{BGBL}, 1946$, No. 156; see also the implementary decree thereto in BGBL, 1947, No. 167.

72 BGBL, 1947, No. 53 .

${ }^{73} \mathrm{BGBL}, 1947$, No. 54; see amendment of June 18,1947 in BGBL, 1947, No. 148.
} 
of the legal owner, restitution is admissible only if the consideration paid was inadequate. Another deviation from the principle of restitution relates to agricultural and forestry properties used for parceling. If restitution is inadvisable because of the economic changes the property has undergone, restitution may be superseded by adequate compensation or (with the consent of the owner) by replacement or by assignment of a part ownership of the changed property. The owner is to repay to the possessor the consideration received within the limits of his free disposal thereof, except that in case of an orderly transaction the non-received price may also be ordered restored. The possessor is responsible for losses due to his fault; he must, as a rule, deliver the usufructs but is entitled to reimbursement of his regular expenses. As a rule; all easements created after alienation are void, but some exceptions are admitted. Restitution is made on the basis of amicable settlements or decisions by special Restitution Commissions (in three court instances).

These three laws were supplemented by two additional enactments: the Fifth Restitution $\mathrm{Law}^{74}$ dealing with properties alienated from legal persons of an economic nature (joint-stock corporation, etc.) which lost their legal personality as a result of acts of persecution, and the Sixth Restitution Law ${ }^{75}$ dealing with restitution of patents and industrial rights.

15. Germany. As a result of the failure of the Allies to achieve uniform restitution legislation in the whole of Germany, ${ }^{76}$ there exist five different restitution enactments: one in each of the four zones and the fifth in Western Berlin. This diversity is one of the greatest anomalies in this field, since alienation was absolutely uniform in the whole German territory and there is no reason for treating the present possessor or the former owner differently just because he happens to live or his property happens to be in a given zone of occupation. The second drawback of this discrepancy is that it creates many unnecessary claims and cases of conflict between the various laws, for instance, when the possessor and the property are in different zones, or when the latter was transported from one to another zone or when the owner had properties in more than one zone. Since the laws were enacted on the basis of "sovereign" discretion by the Military Governors or the local authorities and the Berlin Kommandantura, the conflicting rules are unilateral and no arrangement exists for their coordination.

Another, very important, peculiarity of restitution in Germany is the split in authority. Since the Germans were reluctant to enact proper restitution legislation on their own, the laws were issued by the Western Allies but their application was left (except for the court of the last instance and supervision of the activities of the names.

T4 June 22, 1949-BGBL, 1949, No. 164. The Fourth Restitution Law deals with restoration of firm

T5 June 30, 1949-BGBL, 1949, No. 199.

${ }^{70}$ The only provision enacted by the Four-Power Allied Council in this field is Directive No, 50 on Disposition of Property Having Belonged to Organizations Listed in Control Proclamation No. 2 and Control Council Law No. 2 (Nazi organizations). It provided, i.a., for the return of propertics formerly owned by trade unions, cooperatives, political parties, and other democratic organizations. 
implementing authorities) to the Germans. The only exception is the Thuringian law mentioned below, enacted and implemented by the Germans themselves.

In all cases discussed above, the alienation (except that subject to restoration in Austria) was considered to have been made by the Germans or other occupants or based on foreign influence or insistence. Germany is the only country where it was the direct responsibility of its own former government (even if illegitimate in the view of the Allies and the present local regime) and of the acquirers. The result should have been much stricter rules of restitution and responsibility for non-restitutable properties. In a sense this is actually the case, at least in so far as the law in the United States Zone is concerned; the laws in the British Zone and in Western Berlin are somewhat less strict and that in the French Zone even less so. The existing scant legislation in the Russian Zone is considerably weaker than in any other region.77

Except for the Thuringian restitution law of September I4, I945, and Militàry Government Law No. 52 (enacted in the United States Zone immediately following the occupation of Germany and thereafter in the British Zone, which provided for a certain measure of safeguards for alienated property), the only early practical step in the field of restitution was Decree No. 24 of the French Military Government dated December 8, I945, concerning the declaration of acts of spoliation on grounds of race or opinion. ${ }^{78}$ Not until November 19, 1947, were laws promulgated in the United States and in the French zones. That of the latter was largely patterned after the French decree of April 21, 1945, while the United States zonal law proceeded on the thesis of a "wrongful deprivation"; a presumption of such deprivation which cannot be rebutted except in strictly defined instances; a distinction between the claim for restitution and that of avoidance (granted only when the alienation took place after the proclamation of the Nuremberg laws); the right of the claimant to choose between restitution and the payment of the difference; the difference between a strict and mitigated responsibility of the defendant depending on the manner in which he acquired the property. The course of restitution in the British Zone and Western Berlin was somewhat different in that, preliminary to the enactment of restitution laws, temporary orders were issued which provided not only for the obligatory registration of alienated property by the possessor but also for temporary applications by the former owner. The restitution enactments themselves are largely patterned upon the United States zonal law with the exception that the only remedy provided is a claim for restitution, there is no difference between strict and mitigated responsibility of the possessor, etc.

A special case is afforded by the Saar territory, in which the French zonal law

\footnotetext{
${ }^{77}$ For instance, the right to claim is restricted to near relatives; the owner always has to repay the consideration received; if the possessor refused restitution or the parties cannot agree on the conditions of repayment, a decision is made by a court of arbitration.

For details on restitution in Germany, see the special article on that country in this symposium.

" Jnurnal Officiel du Commandement en Chef Francais en allemagne No. 10.
} 
was at first valid but was amended in July, 1949, by a special Saar law denying restitution in transactions made under the so-called Rome Agreement providing for the right of liquidation of Jewish property within a certain period after the Saar plebiscite, if a fair price was paid, except where individual duress was applied.

The main peculiarity of restitution in the Russian Zone (or Eastern Germany, including Eastern Berlin) is that in only one of the Laender of this region-Thuringia-has a restitution law been enacted while in the rest of the territory restitution is granted on the basis of the general provisions of the German Civil Code providing for the annulment of contracts entered into under duress. ${ }^{79}$ Court practice seems to recognize that racial persecutees were subjected to "collective coercion," and this coercion is a ground for annulling transactions. However, few cases are known where restitution has actually been effected on this basis.

"An exception is afforded by Order No. 82 of the USSR Military Government in Germany dated April 29, 1948, concerning restitution of property confiscated from democratic organizations. 